\title{
Determination of Protein and Carbohydrate Content and Its Correlation with Grain Yield in Foxtail Millet Germplasm
}

\author{
P. Kavya ${ }^{1 *}$, M. Sujatha ${ }^{1}$, S.R. Pandravada ${ }^{2}$ and T.V. Hymavathi ${ }^{3}$ \\ ${ }^{1}$ Department of Genetics and Plant Breeding, College of Agriculture, PJTSAU, \\ Rajendranagar, Hyderabad-500030, Telangana, India \\ ${ }^{2}$ National Bureau of Plant Genetic Resources, Regional Station, Rajendranagar, \\ Hyderabad-500030, Telangana, India \\ ${ }^{3}$ Department of Food and Nutrition, PJTSAU, Rajendranagar, \\ Hyderabad - 500030, Telangana, India \\ *Corresponding author
}

A B S T R A C T

\section{Keywords \\ Foxtail millet, Nutritional traits, Correlation, Grain yield \\ Article Info \\ Accepted: \\ 02 May 2018 \\ Available Online: \\ 10 June 2018}

The present study was conducted for evaluation of 40 foxtail millet germplasm accessions for nutritional traits protein and carbohydrate content and its correlation with grain yield. The experiment was laid out in a randomized complete block design with three replications at National Bureau of Plant Genetic Resources, Regional Station, Rajendranagar, Hyderabad during Kharif, 2015. Average protein content recorded was $10.68 \%$ with a range of 7.66 for accession IS-663 t $13.49 \%$ for KP/SC-1484, while mean values ranged from $56.20 \%$ to $79.90 \%$ with a general mean of $67.54 \%$, KP/SC-1505 accession has recorded highest carbohydrate content while ISE-1511 recorded the lowest. Both the traits negatively correlated with the grain yield.

\section{Introduction}

Foxtail millet one of the minor millet with ample amount of nutritional reserves can become one of the alternative for cereal based consumption with good amount of protein and B-Carotene (Murugan and Nirmalakumari, 2006).

Nutritional composition of foxtail millet per $100 \mathrm{~g}$ edible portion according to (Gopalan et al., 2007) is proteins (12.3 g), carbohydrates $(60.9 \mathrm{~g})$, fat $(4.3 \mathrm{~g})$. The grains have long shelf-life, a preferable attribute (Ravi et al.,
2010). It has been suggested to use foxtail millet protein as a food component to fight type 2 diabetes and cardiovascular diseases (Choi et al., 2005).

Lack of knowledge about use of small millets in the daily diet are the important constraints in promoting their production and consumption, the correlation with grain yield is an important attribute to a breeder for selection of characters and genotypes accordingly so that simultaneously two characters can be improved. 


\section{Materials and Methods}

The present study was carried out on 40 genotypes of foxtail millet having indigenous and exotic collections.

The experiment was laid out in a randomized complete block design with three replications at National Bureau of Plant Genetic Resources, Regional Station, Rajendranagar, Hyderabad during Kharif, 2015. Protein content was estimated by Micro-Kjeldhal method by AOAC procedure which includes

\section{Reagents}

$40 \% \mathrm{NaOH}, 2 \%$ Boric acid, Mixed indicator: $0.2 \%$ bromocresol green and $0.2 \%$ methyl red, Standard 0.5N HCL, Digestion mixture: $98 \mathrm{~g}$ of potassium sulphate and $2 \mathrm{~g}$ of copper sulphate were ground together.

\section{Procedure}

\section{Digestion}

$500 \mathrm{mg}$ of sample, $1 \mathrm{~g}$ of digestion mixture and $10 \mathrm{ml}$ of concentrated $\mathrm{H}_{2} \mathrm{SO}_{4}$ were carefully added and the samples were digested in a digestion block for 1 hour at $375^{\circ} \mathrm{C}$. The tubes were removed and cooled distilled water $(50 \mathrm{ml})$ was added carefully from sides

\section{Distillation}

In a $100 \mathrm{ml}$ conical flask, $40 \mathrm{ml}$ of boric acid was added with a few drops of mixed indicator. Distillation was done in the Gerhardt instrument with the following settings.

Step 1 (NaoH): 50ml

Step 2 (steam digestion time): 10 seconds

Step 3 (distillation time): 180 minutes

\section{Titration}

The contents of conical flask turned green during distillation. Titration was done with standard HCL till the content of the flask turned to original colour (pink). A blank was all run simultaneously.

\section{Calculations}

Titre value $(\mathrm{X}) \mathrm{x} 14.007 \mathrm{x}$ $0.5(\mathrm{~N}$ of $\mathrm{HCl}) \times 6.25$

Protein $(\%)=$------- $x 100$ Weight of sample (mg)

\section{Carbohydrate analysis}

Estimation of carbohydrates by phenolsulphuric acid method (Biochemical Methods Textbook by Sadasivam, 1991).

\section{Principle}

In hot acidic medium glucose is dehydrated to hydroxmethyl furfural. This forms a green coloured product with phenol and has maximum absorption at $490 \mathrm{~nm}$.

\section{Materials}

Phenol 5\% redistilled (reagent grade), Sulphuric acid (96\% reagent grade),

Standard Glucose: Stock - $100 \mathrm{mg}$ in $100 \mathrm{ml}$ of water

Working standard - $10 \mathrm{ml}$ of stock diluted to $100 \mathrm{ml}$ with distilled water

\section{Procedure}

Weigh $100 \mathrm{mg}$ of the sample in a boiling tube, Hydrolyse by keeping it in boiling water bath for $3 \mathrm{hrs}$ with $5 \mathrm{ml}$ of $2.5 \mathrm{~N} \mathrm{HCL}$ and cool to room temperature, neutralize it with solid sodium carbonate until the effervescence 
ceases, make up the volume to $100 \mathrm{ml}$ and centrifuge. Pipette out $0.2,0.4,0.6,0.8$ and 1 $\mathrm{ml}$ of working standard into a series of test tubes, pipette out 0.1 and $0.2 \mathrm{ml}$ of sample solution in two separate test tubes and make up the volume in each tube to $1 \mathrm{ml}$ with water. Set a blank with $1 \mathrm{ml}$ of water, Add $1 \mathrm{ml}$ of phenol solution to each tube, Add $5 \mathrm{ml}$ of sulphuric acid to each tube and shake well, after 10 minutes shake the contents in the tubes and place in water bath at $25-30^{\circ} \mathrm{C}$ for $20 \mathrm{~min}$. Read the colour at $490 \mathrm{~nm}$. Calculate the amount of total carbohydrate present in sample solution using the standard graph.

Calculation: Absorbance corresponds to 0.1 $\mathrm{ml}$ of test $=\mathrm{x} \mathrm{mg}$ of glucose $100 \mathrm{ml}$ of sample solution contains

\section{Calculations}

\section{$\mathrm{X}$ \\ ----- X 100 \\ 0.1}

\section{Results and Discussion}

The analysis of variance for nutritional quality parameters was carried out in 40 germplasm collections. The results are presented in Table 1. The genotypes exhibited highly significant differences for the nutritional parameters viz., protein, carbohydrate and seed yield/plant.

\section{Protein content $(\%)$}

The protein content of millets when compared to rice it is twice higher in the small millets. The recommended dietary allowance for man and women are 60 and 50 grams of protein per day. It is fulfilled by consuming 600 grams of millets instead of 1000 grams of rice. Foxtail millet protein characterization showed that its protein concentrate is a potential functional food ingredient and the essential amino acid pattern suggests possible use as a supplementary protein source to most cereals because it is rich in lysine (Mohamed, T.K 2009). Large amount of variation was observed among the genotypes for protein content ranging from 7.66 to $13.49 \%$ with a mean value of 10.68 per cent (Table 2).

Among the 40 genotypes KP/SC-1484 had highest protein content of 13.49 per cent followed by Sri Lakshmi (12.24\%) and Ise237 (12.19\%). ISE-663 had recorded lowest (7.66 \%), Krishnadevaraya $(8.16 \%)$ followed by IC-436885(8.54\%).

Extremely varying genotypes for protein content were belonging to different geographical origins like Telangana, Andhra Pradesh, Karnataka, Tamil Nadu, Nagaland, Switzerland, Turkey. Hence the present results indicate that vast geographical difference is needed to have diversity for nutrition composition in foxtail millet genotypes (Kamatar et al., 2015).

Out of 40 genotypes, 23 genotypes has more protein content than average value. Among the 23 genotypes most of them possesses high protein content than the multiple checks used. These genotypes can be selected for further breeding programme.

\section{Carbohydrate content (\%)}

Irrespective of high protein foxtail millet also possesses high carbohydrates. Among the 40 genotypes range varies from $56.20 \%$ to 79.90 $\%$ with general mean of $67.54 \%$. Genotype KP/SC-1505 recorded highest carbohydrate content while IS-1511 recorded the lowest followed by IC-426581(59.05\%). Several accessions were leading in the carbohydrate content when compared to the multiple checks. Lower carbohydrates and high protein content in food is desirable for maintenance of good health especially for diabetics and cardiovascular patients. 
Table.1 The mean sum of squares for nutritional characters in 40 foxtail millet germplasm accessions

\begin{tabular}{|l|l|l|l|l|}
\hline S. No & Characters & $\begin{array}{l}\text { Replication } \\
\text { df: } 2\end{array}$ & $\begin{array}{l}\text { Treatments } \\
\text { df: } 39\end{array}$ & $\begin{array}{l}\text { Error } \\
\text { df: } 78\end{array}$ \\
\hline $\mathbf{1}$ & Seed yield/plant $(\mathrm{gm})$ & 72.138 & 700.604 & 24.232 \\
\hline $\mathbf{2}$ & Protein content $\%$ & 0.060 & 5.224 & 0.024 \\
\hline $\mathbf{3}$ & Carbohydrate content $(\%)$ & 1.773 & 94.905 & 0.758 \\
\hline
\end{tabular}

Table.2 Mean values of the nutritional traits in 40 foxtail millet germplasm accessions

\begin{tabular}{|c|c|c|c|c|}
\hline S. NO & GENOTYPE & Seed yield/plant (gm) & PC\% & $\mathrm{CC} \%$ \\
\hline 1 & AR-13 & 22.59 & 10.46 & 77.38 \\
\hline 2 & ISE-200 & 23.80 & 10.70 & 64.08 \\
\hline 3 & ISE-237 & 60.56 & 12.19 & 62.06 \\
\hline 4 & ISE-663 & 29.63 & 7.66 & 65.13 \\
\hline 5 & ISE-1286 & 36.95 & 11.46 & 69.29 \\
\hline$\overline{6}$ & ISE-1511 & 29.99 & 11.00 & 56.20 \\
\hline 7 & LC-1-K.Devaraya & 56.50 & 8.16 & 61.80 \\
\hline 8 & ISE-1629 & 29.23 & 11.15 & 64.04 \\
\hline 9 & SK-13933 & 40.25 & 10.33 & 57.70 \\
\hline 10 & SK-13963 & 37.92 & 11.17 & 69.63 \\
\hline 11 & LC-2-LEPAKSHI & 34.61 & 10.30 & 60.41 \\
\hline 12 & IC-283910 & 30.27 & 11.31 & 56.95 \\
\hline 13 & LC-3-N.charya & 31.06 & 9.84 & 58.26 \\
\hline 14 & IC-283911 & 27.65 & 9.56 & 66.96 \\
\hline 15 & IC-308861 & 22.81 & 12.33 & 73.21 \\
\hline 16 & IC-308939 & 31.28 & 9.95 & 67.15 \\
\hline 17 & LC-4-PRASAD & 31.63 & 10.91 & 68.97 \\
\hline 18 & LC-5-PS4 & 29.71 & 11.47 & 68.00 \\
\hline 19 & LC-6 -SIA-2829 & 28.55 & 11.20 & 67.36 \\
\hline 20 & IC-308981 & 36.27 & 12.69 & 72.08 \\
\hline 21 & LC-7-SIA-2871 & 29.79 & 8.77 & 71.17 \\
\hline 22 & IC-413272 & 46.58 & 10.92 & 69.23 \\
\hline 23 & IC-413275 & 32.31 & 9.67 & 59.05 \\
\hline 24 & IC-426581 & 34.89 & 10.31 & 70.26 \\
\hline 25 & LC-8-Sri Lakshmi & 27.10 & 12.24 & 72.53 \\
\hline 26 & IC-436885 & 35.60 & 8.54 & 61.08 \\
\hline 27 & IC-598145 & 42.33 & 10.24 & 73.52 \\
\hline 28 & IC-610532 & 41.57 & 9.28 & 72.13 \\
\hline 29 & IC-308966 & 24.27 & 11.94 & 69.00 \\
\hline 30 & KP/SC-1452 & 12.03 & 11.92 & 63.09 \\
\hline 31 & KP/SC-1482 & 13.53 & 8.71 & 73.52 \\
\hline 32 & KP/SC-1483 & 10.35 & 10.61 & 71.79 \\
\hline 33 & KP/SC-1484 & 16.57 & 13.49 & 70.69 \\
\hline 34 & KP/SC-1505 & 48.86 & 11.39 & 79.90 \\
\hline 35 & KP/SC-1532 & 5.90 & 12.21 & 67.97 \\
\hline 36 & KP/SC-1579 & 12.90 & 11.43 & 70.08 \\
\hline 37 & KP/SC-1580 & 9.90 & 8.90 & 71.30 \\
\hline 38 & BS-9293 & 36.71 & 11.63 & 71.40 \\
\hline 39 & RJR-608 & 75.64 & 11.60 & 71.07 \\
\hline \multirow[t]{2}{*}{40} & RJR-643 & 71.21 & 9.81 & 66.46 \\
\hline & MEAN & 32.48 & 10.68 & 67.54 \\
\hline
\end{tabular}


High protein and low carbohydrate content, high yield combinations were observed like ISE-237 $\quad(12.19 \% \quad \mathrm{P}, \quad 62.06 \% \quad \mathrm{C}$, $60.56 \mathrm{gm} /$ plant $),$ ISE-1511 (11.00\% P, 56.20 \%C), SE-1629 (11.15\% P, $64.04 \%$ C), IC283910 (11.31 \% P, $56.95 \%$ C) and high yielding genotypes like RJR-608, RJR-643 which are more reliable. But when combined with grain yield both the traits has shown negative association with grain yield which indicates that simultaneous selection for yield and quality traits is not possible.

\section{References}

Choi, Y., Osada, K., Ito, Y., Nagasawa, T., Choi, M. and Nishizawa, N., 2005, Effects of dietary protein of Korean foxtail millet on plasma adinopectin, HDL-cholesterol and insulin levels in genetically type 2 diabetic mice. Biosci. Biotechnol. Biochem., 69, 31-37.

Gopalan C, Ramasastri BV, Balasubramanian SC (2007). Nutritive value of Indian foods, Hyderabad, NIN, ICMR.

Kamatar, M.Y., Brunda, S.M., Rajaput, S., Sowmya, H.H and Goudar, G. 2015. Nutritional Composition of Seventy five
Elite Germplasm of Foxtail Millet (Setaria Italica). International Journal of Engineering Research \& Technology. Vol. 4 Issue 04,

Mohamed, T.K., K. Zhu, A. Issoufou, T. Fatmata and H. Zhou 2009. Functionality, in vitro digestibility and physicochemical properties of two varieties of defatted foxtail millet protein concentrates. International Journal of Molecular Sciences. 10:522438.

Murugan, $\mathrm{R}$ and Nirmalakumari, A. (2006).Genetic divergence in foxtail millet. [Setaria italica (L.) Beauv]. Indian Journal of Genetics. 66(4): 339340.

Ravi, S.B., Hrideek, T.K., Kumar, A.T.K., Prabhakaran, T.R., Mal, B., Padulosi, S., 2010, Mobilizing neglected and underutilized crops to strengthen food security and alleviate poverty in India. Indian Journal of Plant Genetic Resources. 23: 117-121.

Sadasivam, S and Manickam, A. 1991. Biochemical Methods. New Age International Publishers. Pp. 17-19.

\section{How to cite this article:}

Kavya, P., M. Sujatha, S.R. Pandravada and Hymavathi, T.V. 2018. Determination of Protein and Carbohydrate Content and Its Correlation with Grain Yield in Foxtail Millet Germplasm. Int.J.Curr.Microbiol.App.Sci. 7(06): 363-367. doi: https://doi.org/10.20546/ijcmas.2018.706.040 